\title{
A study on the activity of dermal multipotent stem cells in initiation of wound repair
}

\author{
Jifu Qu ${ }^{1,2}$, Tianmin Cheng ${ }^{2}$, Yongping $\mathrm{Su}^{2}$, Chunmeng Shi ${ }^{2}$, Wei Sun ${ }^{1}$ \\ ${ }^{1}$ Trauma Center, Department of Emergency Medicine, Southwest Hospital, Third Military Medical University, Chongqing, China \\ ${ }^{2}$ State Key Laboratory of Trauma, Burn and Combined Injury, Institute of Combined Injuries of Chinese PLA, Academy of Preven- \\ tive Medicine, Third Military Medical University, Chongqing, China \\ Email: qujifu@yahoo.cn
}

Received 17 December 2012; revised 16 January 2013; accepted 24 January 2013

\section{ABSTRACT}

Background: Wound healing is a process of cell-cell interaction and cell-extracellular matrix interaction. Dermal multipotent stem cells (dMSCs) have the abilities to promote survival and wound healing, but the potential function of dMSCs in wound healing, particularly in the initiation of wound repair, has not been fully understood. Methods: dMSCs and fibroblasts were isolated from neonatal rat dermis and were further purified and expanded. The cell cycles were determined with flow cytometry, while the radiosensitivity was measured by MTT assay. Rats were wounded with a 7-cm incision on the back skin and the wound fluids were collected by inserting two pieces of sterile polyvinyl alcohol sponge $(1 \mathrm{~cm}$ in diameter and $0.4 \mathrm{~cm}$ in thickness) subcutaneously into the dorsum of each rat through the midline of incision on the $1^{\text {st }}, 2^{\text {nd }}, 3^{\text {rd }}$ and $4^{\text {th }}$ day after incision. The effects of wound fluids on the proliferation of dMSCs and fibroblasts were measured with MTT assays. dMSC's abilities of adhesion and attachment and its migration in response to wound fluids collected on the $1^{\text {st }}$ day after incision were explored by measuring the percentage of floating cells and the cells migrated into wounding area in vitro, respectively. Results: The isolated dMSCs were morphologically homogenous and highly proliferative. Most of the cultured dMSCs were quiescent with few apoptotic cells. Compared with fibroblasts, dMSCs were more sensitive to radiation and more proliferative in response to wound fluids, especially to the wound fluids collected on the $\mathbf{1}^{\text {st }}$ day after wounding. Moreover, their abilities to attach, adhere and migrate were significantly enhanced with the early-phase wound fluids. Conclusions: As primitive stem cells, dMSCs are very responsive to wound fluids, which suggests dMSCs' important role in wound healing, especially in initiating wound repair.
Keywords: Dermal Multipotent Stem Cells; Initiation of Wound Repair; Wound Healing; Wound Fluids

\section{INTRODUCTION}

Stem cells are cells with self-renewal capacity, multipotentiality and unparalleled superiority in cell-replacement therapy, gene therapy, developmental biology, pharmacology and toxicology $[1,2]$. Mesenchymal stem cells have the potential to differentiate into fibroblasts, vascular endothelial cells and other tissue repairing cells, therefore playing important roles in tissue repair [3]. Recent studies have suggested that stem cells with different developmental potentials exist in several adult mammalian tissues, especially in newly formed tissues or tissues with rapid renewal potentials [4-6]. Skin, which consists of the epidermis and dermis, is one of the rapidly renewing tissues in adults. Several studies from our group and two other groups have indicated that multipotent cells can be isolated from adult mammalian dermis $[4,7,8]$. Given their easy accessibility, these cells could be a source of stem cells for cell transplantation and tissue engineering. Particularly, we have found that multipotent stem cells derived from dermal mesenchymal tissue, namely dMSCs, have the abilities to promote survival and wound healing in rats subjected to radiation and wound injury, as well as enhance hematopoietic recovery in sublethally irradiated rats $[9,10]$.

Wound healing is a process of cell-cell interaction and cell-extracellular matrix interaction. Wound environments exert significant effects on cell growth and differentiation during the healing process. Different cell types are activated by the environment and subsequently migrate to and proliferate at the wound site. Studies have indicated that it is the specific tissue environment that determines the plasticity of mesenchymal stem cells in vivo [11-14]. Although activation of epithelial cells, fibroblasts and endothelial cells has been observed after wounding, little has been described about the multipotent cells in the 
dermis [15-18]. In our previous study, we investigated the biological effects of the acute wound environment (wound fluids) on dMSCs isolated from newborn rats (neonatal dMSCs), and showed that neonatal suspensions enhanced the initial rate of wound contraction and some cells differentiated from dMSCs were found in the regenerative dermis. We also observed that treatment with acute wound fluid promoted proliferation and migration of dMSCs [4]. These results suggest that neonatal dMSCs could participate in the regeneration of the injured dermis and thus may be an alternative choice for cell-based therapies for skin injuries.

As stem cells are primitive with self-renewal capacity, it awaits clarification whether the dMSCs are primitive stem cells. Moreover, the potential function of dMSCs in wound healing has also not been fully understood. In the present study, we further characterized the radiosensitivity of dMSCs, as well as their proliferation, attachment, adhesion and migration in response to early-phase wound fluids so as to explore their potential roles in wound healing.

\section{MATERIALS AND METHODS}

\subsection{Cell Culture}

dMSCs and fibroblasts were isolated from neonatal rat dermis, cultured in IMDM supplemented with $10 \%(\mathrm{v} / \mathrm{v})$ fetal bovine serum, $100 \mathrm{U} / \mathrm{mL}$ penicillin and $100 \mu \mathrm{g} / \mathrm{mL}$ streptomycin (Hyclone). dMSCs were amplified and identified as previously described [9]. Briefly, skin tissue from 1-day-old rat was digested with $0.25 \%$ trypsin at $4^{\circ} \mathrm{C}$ overnight. The dermal layer (confirmed with histological examination) was dissociated by flushing with D-Hanks' solution; the suspension was filtered through a nylon mesh and centrifuged to remove cellular debris. The cell pellet was resuspended and cultured in IMDM containing $10 \%$ FBS, $100 \mathrm{U} / \mathrm{mL}$ penicillin and 100 $\mu \mathrm{g} / \mathrm{mL}$ streptomycin at $37^{\circ} \mathrm{C}$ in a humidified atmosphere containing $5 \% \mathrm{CO}_{2}$. Six hours later, the adherent cells were subcultured at a low density of 5 cells $/ \mathrm{cm}^{2}$. The presence of separately adherent single cell was assessed microscopically. Two weeks later, single colonies were isolated by cloning rings under an inverted microscope and expanded. The differentiation characteristics of dMSC were further confirmed in an induction medium containing dexamethasone as reported previously [4].

\subsection{Radiosensitivity Measurement by MTT Assay}

Radiosensitivities of fibroblasts and the $10^{\text {th }}$ passage of dMSCs were measured by MTT assay. $80 \%$ confluent cells were detached with $0.25 \%$ trypsin. After washed once with D-Hank's solution, the cell concentration was adjusted to $2 \times 10^{4} / \mathrm{mL}$ with IMDM supplemented with $10 \mathrm{ml} / \mathrm{L}$ fetal bovine serum. $0.2 \mathrm{ml}$ cells were transferred into sterile penicillin bottles and irradiated with ${ }^{60} \mathrm{Co} \gamma$ ray at $0,2,6,10,12$ and $15 \mathrm{~Gy}$, respectively. After irradiation, the cells were added into 96-well plate and the numbers of live cells were measured with MTT assay in quadruplicate for each radiation dosage. Specifically, $20 \mu \mathrm{L} 5 \mathrm{~g} / \mathrm{L}$ MTT solution (Sigma) was added into each well of the 96-well plate and incubated for 4 hours at $37^{\circ} \mathrm{C}$ in a humidified atmosphere containing $5 \% \mathrm{CO}_{2}$. Then the culture solution was removed and $150 \mu \mathrm{L}$ DMSO was added into each well and oscillated for 10 minutes. The absorptions at $492 \mathrm{~nm}$ were measured with an enzyme immunoassay analyzer (HTS 7000 plus, Perkin Elmer, USA).

\subsection{Measurement of Cell Cycle and Apoptotic Rate}

The changes in cell cycle progression and apoptotic rate of dMSCs at the $3^{\text {rd }}$ passage were assayed with flow cytometry. $80 \%$ confluent cells were detached with $0.25 \%$ trypsin. After washed once with D-Hank's solution, the cells were fixed for $30 \mathrm{~min}$ with $70 \%$ alcohol at $4^{\circ} \mathrm{C}$, and then centrifuged at $1500 \mathrm{rpm}$ for $5 \mathrm{~min}$. After discarding the fixing solution, the cells were washed once with cold PBS solution. dMSC cells were incubated with $200 \mu$ of lysis buffer, stained with propidium iodide at a concentration of $50 \mathrm{mg} / \mathrm{mL}$ for $15 \mathrm{~min}$, and analyzed with the Coulter Epic C flow cytometer to calculate the G0/G1 population and apoptotic rate.

\subsection{Collection of Rat Wound Fluids}

Wistar rats were bred and fed in Animal Center of our university with first class standard. All animal procedures were approved by the institution's animal-use committee and by the Ministry of Justice. 15-week old Wistar rats of mixed sex were wounded with a $7-\mathrm{cm}$ incision on the back skin and the wound fluids were collected by inserting two pieces of sterile polyvinyl alcohol sponges $(1 \mathrm{~cm}$ in diameter and $0.4 \mathrm{~cm}$ in thickness) subcutaneously in the dorsum of each animal through the midline incision [10]. The rats were then sacrificed on the $1^{\text {st }}, 2^{\text {nd }}, 3^{\text {rd }}$ and $4^{\text {th }}$ day after wounding. The wound fluids were collected from the sponge after the cellular components were removed by centrifugation and sterilized with a $0.2 \mu \mathrm{m}$ filter and then stored at $-20^{\circ} \mathrm{C}$ until use.

\subsection{Effect of Wound Fluids on Proliferation of dMSCs}

After 48-hour culture in serum-free IMDM [19], cells were plated at $2 \times 10^{4} / \mathrm{mL}$ to 96 -well plate. The wound fluids were added at various concentrations of $10 \mathrm{ml} / \mathrm{L}$, 
$20 \mathrm{ml} / \mathrm{L}$ and $30 \mathrm{ml} / \mathrm{L}$ and the cells were further incubated for 24 hours. The control group cells were not treated with wound fluids $(0 \mathrm{ml} / \mathrm{L})$. The numbers of live cells were then measured by MTT assay. Each experiment was performed 3 times in quadruplicate.

\subsection{Effect of Wound Fluids on dMSC Attachment}

dMSCs were cultured in flasks and maintained in serum-free IMDM for 48 hours. Then the cells were incubated with either IMDM plus $10 \mathrm{ml} / \mathrm{L}$ wound fluids collected on the first day after rats were wounded or IMDM alone for 6 hours. The cells were then detached with $0.25 \%$ trypsin and $2 \times 10^{5}$ cells were inoculated into culture flasks. After incubation for 6 hours, cells remained floating in the flasks were then collected and counted. The percentages of attached cells were calculated [20].

\subsection{Effect of Wound Fluids on dMSC Adhesion}

dMSCs were cultured in flask and maintained in serumfree IMDM for 48 hours. Then the cells were further cultured in IMDM alone or IMDM plus $10 \mathrm{ml} / \mathrm{L}$ wound fluids, which were collected on the first day after rats were wounded. 24 hours later, the dMSCs were digested with $0.25 \%$ trypsin for 2 minutes to lift cells that loosely adhered to the flask and the digestion was stopped with serum. The suspended cells were collected and counted. The cells remained adhered were scraped, collected and counted. The adhesion ability of cells was calculated as percentages of suspended cells in the total of suspended and adhered cells [20].

\subsection{Effect of Wound Fluids on dMSC Migration}

Cell motility was analyzed using an in vitro wound model of cell monolayer. Synchronized dMSCs were inoculated at $2 \times 10^{5}$ well into 24 -well plate and cultured for three days to reach $80 \%$ confluency. The cells were then cultured in IMDM alone in the control group or IMDM supplemented with $10 \mathrm{ml} / \mathrm{L}$ wound fluids in the experimental group. After incubated for 24 hours, the cell monolayer was scratched to form a $1 \mathrm{~mm}$-wide clear area using a sterile needle. 8 hours later, the number of cells migrated into the wounded area was measured with an inverted light microscope. The migration rates were expressed as the number of migrated cells per field and the percentage of the shortened wound width [4].

\subsection{Statistical Analysis}

Data were analyzed using paired Student's t-test with SPSS11.0 statistical software. Results were expressed as mean $\pm \mathrm{SD}(\bar{x} \pm \mathrm{s}) . \mathrm{p}<0.05$ was considered statisticcally significant.

\section{RESULTS}

\subsection{Effect of Radiation on Survival and Cell Cycle Progression of dMSCs}

As previously described, the isolated dMSCs were smooth and homogenous in morphology in culture, and they maintained strong proliferative activity after being subcultured for more than ten passages. The survival rate of dMSCs in response to different dosages of $\gamma$ irradiation was measured by MTT assay and compared to fibroblasts. As shown in Table 1, dMSCs tolerated irradiation at a dose of $2 \mathrm{~Gy}$, but their survival rate was significantly decreased by increasing dose of irradiation from 6 Gy to 15 Gy. By contrast, fibroblasts were less sensitive to irradiation, showing good tolerance to irradiation up to the dose of 10 Gy (Table 2) and only susceptible to higher dosages of irradiation (12 Gy to 15 Gy). As higher sensitivity generally reflects stronger primitiveness of the cells, our results here suggest that dMSCs are more primitive cells compared to fibroblasts. Further supporting this, flow cytometry analysis indicated that most of the dMSCs cultured in vitro were in quiescent state with $95 \%$ population in $\mathrm{G} 0 / \mathrm{G} 1$ phase and only $0.34 \%$ apoptotic cells (Figure 1). After radiation with $15 \mathrm{~Gy}{ }^{60} \mathrm{Co} \gamma$ ray, the number of apoptotic cells increased by $20 \%$ (Figure 2).

Table 1. Dosage effect of $\gamma$ radiation on the growth of dMSCs.

\begin{tabular}{ccccccc}
\hline${ }^{60}$ Co dosage & $0 \mathrm{~Gy}$ & $2 \mathrm{~Gy}$ & $6 \mathrm{~Gy}$ & $10 \mathrm{~Gy}$ & $12 \mathrm{~Gy}$ & $15 \mathrm{~Gy}$ \\
\hline $\mathrm{A} 490 \mathrm{~nm}$ & $1.095 \pm 0.084$ & $1.303 \pm 0.071^{*}$ & $1.177 \pm 0.015$ & $1.030 \pm 0.026$ & $0.877 \pm 0.031^{*}$ & $0.821 \pm 0.073^{\#}$ \\
\hline
\end{tabular}

Cell growth was measured by MTT assay and presented as absorption values at $490 \mathrm{~nm}$ wavelength. Data represented four independent experiments. ${ }^{*} \mathrm{p}<0.05$, ${ }^{\#} \mathrm{p}<0.01$ compared with no radiation group.

Table 2. Dosage effect of $\gamma$ radiation on the growth of fibroblasts.

\begin{tabular}{ccccccc}
\hline${ }^{60}$ Co dosage & $0 \mathrm{~Gy}$ & $2 \mathrm{~Gy}$ & $6 \mathrm{~Gy}$ & $10 \mathrm{~Gy}$ & $12 \mathrm{~Gy}$ & $15 \mathrm{~Gy}$ \\
\hline $\mathrm{A} 490 \mathrm{~nm}$ & $0.238 \pm 0.041$ & $0.260 \pm 0.032$ & $0.166 \pm 0.012^{*}$ & $0.074 \pm 0.006^{*}$ & $0.060 \pm 0.007^{*}$ & $0.059 \pm 0.005^{*}$ \\
\hline
\end{tabular}

Cell growth was measured by MTT assay and presented as absorption values at $490 \mathrm{~nm}$ wavelength. Data represented four independent experiments. ${ }^{*} \mathrm{p}<0.05$ compared with no radiation group. 


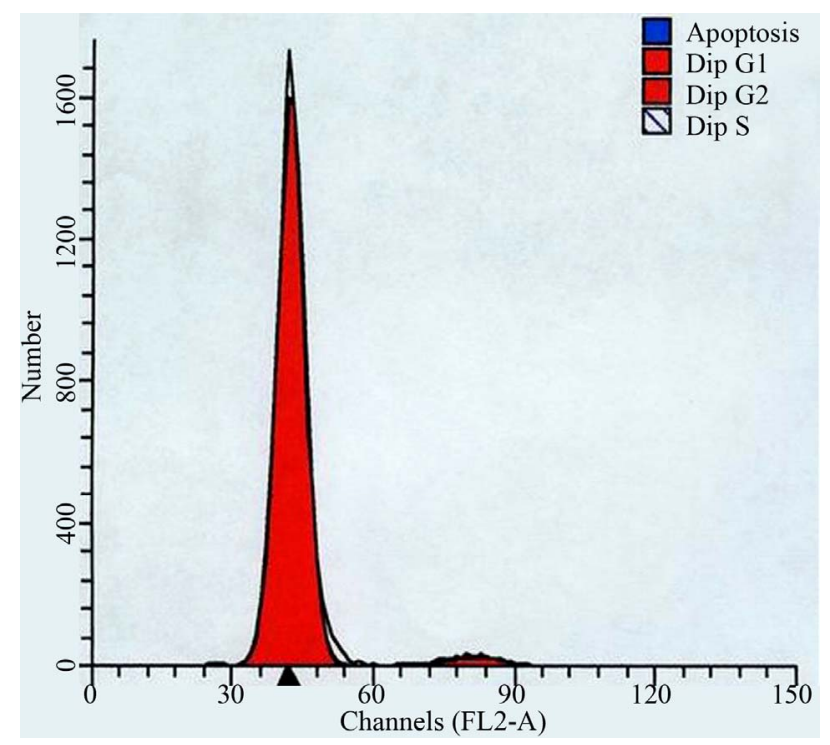

Figure 1. Flow cytometry of dMSCs cultured in normal conditions.

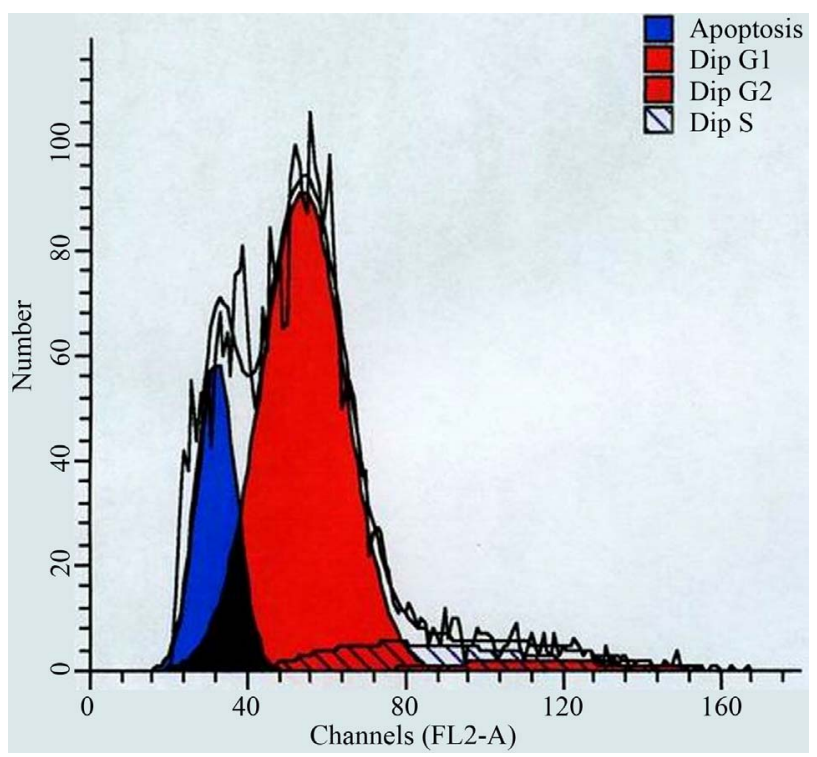

Figure 2. Flow cytometryof dMSCs irradiated by 15 Gy ${ }^{60} \mathrm{Co} \gamma$ ray.

\subsection{Effect of Wound Fluids on dMSC Proliferation}

We next examined the proliferation of dMSCs in response to wound fluids collected on the $1^{\text {st }}, 2^{\text {nd }}, 3^{\text {rd }}$ and $4^{\text {th }}$ day after the rats were wounded. As shown in Table 3, would fluids of different concentrations and from various time points all significantly stimulated the proliferation of dMSCs. Notably, wound fluids collected on the $1^{\text {st }}$ and $2^{\text {nd }}$ day after wounding showed a greater stimulatory effect on dMSCs proliferation than those collected on the $3^{\text {rd }}$ and $4^{\text {th }}$ day. In addition, the wound fluids applied at lower concentration $(10 \mathrm{ml} / \mathrm{L})$ more strongly augmented
Table 3. Effect of wound fluids on dMSC proliferation $(\bar{x} \pm \mathrm{s})$.

\begin{tabular}{ccccc}
\hline \multirow{2}{*}{$\begin{array}{c}\text { Concentration } \\
(\mathrm{mL} / \mathrm{L})\end{array}$} & 1 & 2 & 3 & 4 \\
\cline { 2 - 5 } & $1.30 \pm 0.18$ & $1.30 \pm 0.06$ & $0.93 \pm 0.11^{\mathrm{b}}$ & $1.01 \pm 0.25^{\mathrm{b}}$ \\
10 & $1.15 \pm 0.24$ & $1.05 \pm 0.17^{\mathrm{a}}$ & $0.77 \pm 0.07^{\mathrm{b}}$ & $0.90 \pm 0.09^{\mathrm{b}}$ \\
20 & $0.98 \pm 0.14^{\mathrm{a}}$ & $0.78 \pm 0.06^{\mathrm{a}}$ & $0.76 \pm 0.16$ & $0.76 \pm 0.04^{\mathrm{a}}$ \\
30 &
\end{tabular}

Data represented four independent experiments. Values of the control group: $0.33 \pm 0.02 ;^{\mathrm{a}}$ : $\mathrm{p}<0.05 \mathrm{vs} 10 \mathrm{ml} / \mathrm{L}$ group of the same time; ${ }^{\mathrm{b}}: \mathrm{p}<0.05 \mathrm{vs} 1^{\text {st }}$ day group of the same concentration.

the proliferation of dMSCs as compared to would fluids diluted at $20 \mathrm{ml} / \mathrm{L}$ or $30 \mathrm{ml} / \mathrm{L}$.

\subsection{Effect of Early-Stage Wound Fluids on dMSC Attachment, Adhesion and Migration}

Since the wound fluid collected on the first day after the rats were wounded showed the most significant effect on cell growth, we further examined its effect on the attachment, adhesion and migration of dMSCs. Table 4 showed that stimulation with the $1^{\text {st }}$ day wound fluid significantly enhanced the attachment ability of dMSCs, as indicated by the increase in the percentage of cells attached to culture flasks from $58.84 \% \pm 6.91 \%$ in the control group to $80.42 \% \pm 8.52 \%$ in the wound fluidtreated group. Similarly, the percentage of adherent $\mathrm{dMSCs}$ also increased from $45.56 \% \pm 4.63 \%$ in the control group to $74.95 \% \pm 7.67 \%$ in the wound fluid-treated group. Using the in vitro wound repair model, we further found that treatment with early-stage wound fluid significantly increased the number of dMSCs migrated into the wounded area (120.84 \pm 13.31 per field) compared to the control group $(60.78 \pm 4.28$ per field), and increased the percentage of recovered wound area from $54.28 \% \pm$ $3.63 \%$ to $85.47 \% \pm 8.53 \%$, suggesting that the woundfluid stimulation enhanced dMSCs migration (Figure 3, Table 5).

\section{DISCUSSIONS}

In the present study, we demonstrate that dMSC are primitive cells based on their high sensitivity to irradiation and low apoptotic rate in steady state. Our previous study showed that dMSCs were able to not only maintain a strong proliferative capacity after being sub-cultured for more than ten passages with uniformed morphology, but also differentiate into osteoblasts and lipocytes. Collectively, these data demonstrate that dMSCs are relatively primitive mesenchymal multipotent stem cells with the capacity of self-renewal and multi-directional differentiation.

Wound healing is a complex process requiring the collaborative efforts of different cell types and the local environment [21]. Most tissue-repairing cells are in qui- 
Table 4. Effect of $1^{\text {st }}$-day wound fluid on attachment and adhesion of dMSCs $(\bar{x} \pm \mathrm{s})$.

\begin{tabular}{ccc}
\hline & Experimental group & Control group \\
\hline Attachment (\%) & $80.42 \pm 8.52^{*}$ & $58.84 \pm 6.91$ \\
Adhesion (\%) & $74.95 \pm 7.67^{*}$ & $45.56 \pm 4.63$ \\
\hline
\end{tabular}

Data represented four independent experiments. ${ }^{*}: \mathrm{p}<0.05$ vs the control group.
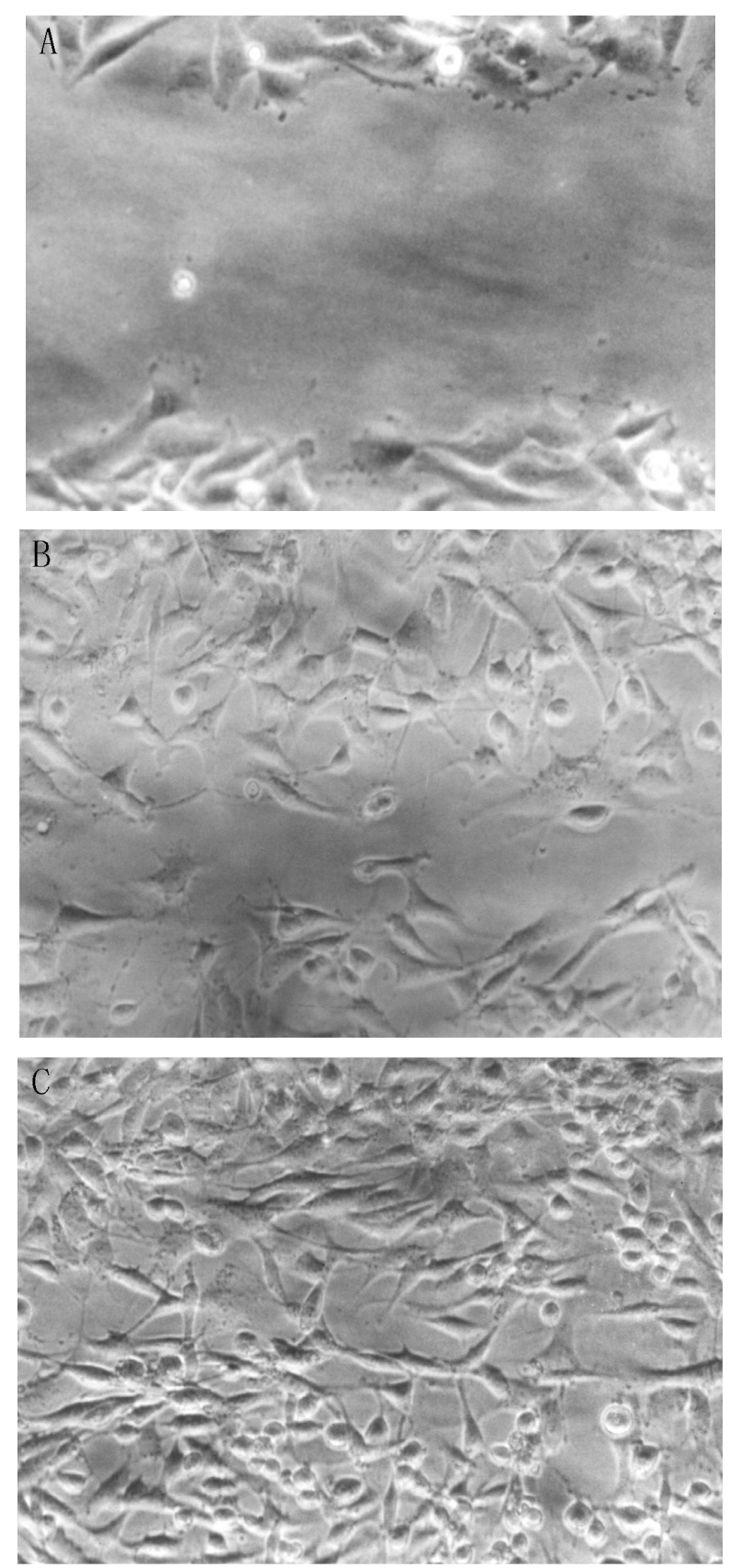

Figure 3. Representative microscopic images of dMSCs in the in vitro wound repair assay. (A) Immediately after wounding of the monolayer $200 \times$; (B) 8 hours after wounding, without treatment $200 \times$; (C) 8 hours after wounding, treated with wound fluids $200 \times$.
Table 5. Effect of $1^{\text {st }}$-day wound fluid on dMSC migration $(\bar{x} \pm \mathrm{s})$.

\begin{tabular}{ccc}
\hline & $\begin{array}{c}\text { Cell number (between the } \\
\text { scratch lines /per field) }\end{array}$ & $\begin{array}{c}\text { Percent of shrinking } \\
\text { area (\%) }\end{array}$ \\
\hline Experimental group & $120.84 \pm 13.31^{*}$ & $85.47 \pm 8.53^{*}$ \\
Control group & $60.78 \pm 4.28$ & $54.28 \pm 3.63$ \\
\hline
\end{tabular}

Data represented four independent experiments. ${ }^{*}: \mathrm{p}<0.05$ vs the control group.

escent state until stimulated by wound fluids to express specific genes and then initiate the tissue repair process. Migration and proliferation of these cells at the wound site is important for tissue granulation and repair, whereas their attachment and adhesion abilities are essential to prevent external injuries [20]. Our present study shows that dMSCs are in quiescent G0/G1 phase without stimulation, and their proliferation, migration, attachment and adhesion were significantly enhanced in response to wound fluids, suggesting the important roles of these cells in wound healing and tissue repairing. Specifically, the stronger responsiveness of dMSCs to the wound fluids collected on the $1^{\text {st }}$ and $2^{\text {nd }}$ day after wounding than those collected on the $3^{\text {rd }}$ and $4^{\text {th }}$ day after wounding indicate their potential role in the initiation of wound repair. Wound fluids are known to contain a variety of cytokines and growth factors such as TGF-alpha, TGF-beta1, TNFalpha, PDGF-AA and IGF, as well as lysophospholipids such as S1P, LPA and LPCs which regulate wound healing via activation of tissue-repairing cells [19,22-24]. Our previous study found that the levels of TNF-alpha, bFGF and nerve growth factor (NGF) were significantly increased in the wound fluids or wound sites during the early stage after wounding $[25,26]$. Marikovsky et al. reported that the activity of growth factors such as IGF-1 and HB-EGF, appeared 1 day after injury, reached maximal in 2-3 days and disappeared by 6 days after injury [23]. Dvonch et al. showed that both the concentration and the biologic activity of PDGF AA and monocyte/macrophage-derived growth factor (MDGF) were highest in the immediate postoperative period and declined to negligible levels by 24 hours after surgery. Such alterations in cytokines and growth factors might explain why wound fluids collected from early stage (1 - 2 days) are more effective in stimulating dMSCs. Further study is necessary to reveal the molecular mechanisms by which these cytokines and growth factors in wound fluids regulate dMSCs.

In conclusion, dMSCs are relatively primitive mesenchymal stem cells that are highly responsive to wound fluids and likely to play important roles in the initiation of wound repair. The easy accessibility of dMSCs via skin biopsy makes them a particularly attractive source of dermis-derived multipotent cells for cell replacement 
therapies or for treatment of skin injury.

\section{ACKNOWLEDGEMENTS}

This study was supported by National Science Foundation of China (30370562, 81071562), the 973 Project of National Basic Research Program of China (G1999054205 and 2005CB522605).

\section{REFERENCES}

[1] Wakayama, T., Tabar, V., Rodriguez, I., Perry, A.C., Studer, L. and Mombaerts, P. (2001) Differentiation of embryonic stem cell lines generated from adult somatic cells by nuclear transfer. Science, 292, 740-743. doi:10.1126/science.1059399

[2] Wei, G., Schubiger, G., Harder, F. and Müller, A.M. (2000) Stem cell plasticity in mammals and transdetermination in drosophila: Common themes? Stem Cells, 18, 409-414. doi:10.1634/stemcells.18-6-409

[3] Sekiya, I., Larson, B.L., Smith, J.R., Pochampally, R., Cui, J.G. and Prockop, D.J. (2002) Expansion of human adult stem cells from bone marrow stroma: Conditions that maximize the yields of early progenitors and evaluate their quality. Stem Cells, 20, 530-541. doi:10.1634/stemcells.20-6-530

[4] Shi, C. and Cheng, T. (2003) Effects of acute wound environment on neonatal rat dermal multipotent cells. Cells Tissues Organs, 175, 177-185. doi:10.1159/000074939

[5] Slack, J.M. (2000) Stem cells in epithelial tissues. Science, 287, 1431-1433. doi:10.1126/science.287.5457.1431

[6] Vogel, G. (1999) Breakthrough of the year. Capturing the promise of youth. Science, 286, 2238-2239. doi:10.1126/science.286.5448.2238

[7] Toma, J.G., Akhavan, M., Fernandes, K.J., Barnabé-Heider, F., Sadikot, A., Kaplan, D.R. and Miller, F.D. (2001) Isolation of multipotent adult stem cells from the dermis of mammalian skin. Nature Cell Biology, 3, 778-784. doi:10.1038/ncb0901-778

[8] Young, H.E., Steele, T.A., Bray, R.A., Hudson, J., Floyd, J.A., Hawkins, K., Thomas, K., Austin, T., Edwards, C., Cuzzourt, J., Duenzl, M., Lucas, P.A. and Black Jr., A.C. (2001) Human reserve pluripotent mesenchymal stem cells are present in the connective tissues of skeletal muscle and dermis derived from fetal, adult, and geriatric donors. The Anatomical Record, 264, 51-62. doi:10.1002/ar.1128

[9] Shi, C., Cheng, T., Su, Y., Mai, Y., Qu, J., Lou, S., Ran, X., Xu, H. and Luo, C. (2004) Transplantation of dermal multipotent cells promotes survival and wound healing in rats with combined radiation and wound injury. Radiation Research, 162, 56-63. doi:10.1667/RR3189

[10] Shi, C.M., Cheng, T.M., Su, Y.P., Mai, Y., Qu, J.F. and Ran, X.Z. (2004) Transplantation of dermal multipotent cells promotes the hematopoietic recovery in sublethally irradiated rats. Journal of Radiation Research, 45, 19-24. doi:10.1269/jrr.45.19

[11] Azizi, S.A., Stokes, D., Augelli, B.J., DiGirolamo, C. and
Prockop, D.J. (1998) Engraftment and migration of human bone marrow stromal cells implanted in the brains of albino rats-Similarities to astrocyte grafts. Proceedings of the National Academy of Sciences of the USA, 95, 39083913. doi:10.1073/pnas.95.7.3908

[12] Ferrari, G., Cusella-De Angelis, G., Coletta, M., Paolucci, E., Stornaiuolo, A., Cossu, G. and Mavilio, F. (1998) Muscle regeneration by bone marrow-derived myogenic progenitors. Science, 279, 1528-1530. doi:10.1126/science.279.5356.1528

[13] Mezey, E., Chandross, K.J., Harta, G., Maki, R.A. and McKercher, S.R. (2000) Turning blood into brain: Cells bearing neuronal antigens generated in vivo from bone marrow. Science, 290, 1779-1782. doi:10.1126/science.290.5497.1779

[14] Petersen, B.E., Bowen, W.C., Patrene, K.D., Mars, W.M., Sullivan, A.K., Murase, N., Boggs, S.S., Greenberger, J.S. and Goff J.P. (1999) Bone marrow as a potential source of hepatic oval cells. Science, 284, 1168-1170. doi:10.1126/science.284.5417.1168

[15] Katz, M.H., Alvarez, A.F., Kirsner, R.S., Eaglstein, W.H. and Falanga, V. (1991) Human wound fluid from acute wounds stimulates fibroblast and endothelial cell growth. Journal of the American Academy of Dermatology, 25, 1054-1058. doi:10.1016/0190-9622(91)70306-M

[16] Regan, M.C., Kirk, S.J., Wasserkrug, H.L. and Barbul, A. (1991) The wound environment as a regulator of fibroblast phenotype. Journal of Surgical Research, 50, 442448. doi:10.1016/0022-4804(91)90022-E

[17] Schäffer, M.R., Tantry, U., Ahrendt, G.M., Wasserkrug, H.L. and Barbul, A. (1997) Stimulation of fibroblast proliferation and matrix contraction by wound fluid. The International Journal of Biochemistry \& Cell Biology, 29, 231-239. doi:10.1016/S1357-2725(96)00136-7

[18] Zieske, J.D. (2001) Extracellular matrix and wound healing. Current Opinion in Ophthalmology, 12, 237-241. doi:10.1097/00055735-200108000-00001

[19] Amano, S., Akutsu, N., Ogura, Y. and Nishiyama, T. (2004) Increase of laminin 5 synthesis in human keratinocytes by acute wound fluid, inflammatory cytokines and growth factors, and lysophospholipids. British Journal of Dermatology, 151, 961-970. doi:10.1111/j.1365-2133.2004.06175.x

[20] Qu, J., Cheng, T., Shi, C., Lin, Y. and Ran, X. (2004) A study on the activity of fibroblast cells in connection with tissue recovery in the wounds of skin injury after whole-body irradiation. Journal of Radiation Research, 45, 341-344. doi:10.1269/jrr.45.341

[21] Martin, P. (1997) Wound healing-Aiming for perfect skin regeneration. Science, 276, 75-81. doi:10.1126/science. 276.5309 .75

[22] Dvonch, V.M., Murphey, R.J., Matsuoka, J. and Grotendorst, G.R. (1992) Changes in growth factor levels in human wound fluid. Surgery, 112, 18-23.

[23] Marikovsky, M., Vogt, P., Eriksson, E., Rubin, J.S., Taylor, W.G., Joachim, S. and Klagsbrun, M. (1996) Wound fluid-derived heparin-binding EGF-like growth factor (HBEGF) is synergistic with insulin-like growth factor-I for Balb/MK keratinocyte proliferation. Journal of Investiga- 
tive Dermatology, 106, 616-621. doi:10.1111/1523-1747.ep12345413

[24] Kroeze, K.L., Jurgens, W.J., Doulabi, B.Z., van Milligen, F.J., Scheper, R.J. and Gibbs, S. (2009) Chemokine-mediated migration of skin-derived stem cells: Predominant role for CCL5/RANTES. Journal of Investigative Dermatology, 129, 1569-1581. doi:10.1038/jid.2008.405

[25] Qu, J.F., Cheng, T.M., Shi, C.M., Lin, Y., Yan, G.H. and Ran, X.Z. (2002) Changes of contents of wound bFGF and NGF after combined total body irradiation (TBI) injury. Chinese Journal of Radiological Medicine \& Protection, 22, 158-160.

[26] Song, S.Q., Cheng, T.M. and Lin, Y. (1998) Changes of cytokines in wound fluids and the effects of phenytoin sodium on whole body irradiated rats. Basic Medicine \& Clinical, 18, 208-211. 